\title{
Effect of dietary copper deficiency in the rat on fatty acid composition of adipose tissue and desaturase activity of liver microsomes
}

\author{
By K. W. J. WAHLE AND N. T. DAVIES \\ Rowett Research Institute, Bucksburn, Aberdeen $A B 29 S B$ \\ (Received I October 1974-Accepted 4 November 1974)
}

\begin{abstract}
1. Male rats were maintained from weaning to between 4 and 16 weeks of age on a semisynthetic diet which was deficient in copper.

2. Methyl esters of fatty acids from adipose tissue of the rats were analysed by gas-liquid chromatography and the desaturase activity of liver microsomes, with $\left[{ }^{14} \mathrm{C}\right] \mathrm{stearic}$ acid as the substrate, was determined. Liver and plasma $\mathrm{Cu}$ concentration, cytochrome $c$ oxidase $(E C \mathrm{I} .9 .3 . \mathrm{I})$ activity and caeruloplasmin activity were determined as indices of $\mathrm{Cu}$ status.

3. $\mathrm{Cu}$ deficiency was associated with decreased mono-unsaturated : saturated ratios for $\mathrm{C}_{18}$ and $\mathrm{C}_{18}$ fatty acids from subcutaneous adipose tissue and decreased desaturase activity for liver microsomes. When $\mathrm{Cu}$-deficient rats were given free access to the $\mathrm{Cu}$-adequate diet or were injected intraperitoneally with an aqueous solution of $\mathrm{CuSO}_{4}$, that is, when the animals were repleted with $\mathrm{Cu}$, the indices of $\mathrm{Cu}$ status, and desaturase activity for liver microsomes returned to values found in control animals.

4. When $\mathrm{Cu}$ or a $\mathrm{Cu}$-chelator (Neocuproine) was added to microsomes, there was no effect on the activity of the desaturase enzyme system; the stability of the desaturase was not affected by $\mathrm{Cu}$.

5. These results are indicative of an involvement of $\mathrm{Cu}$ in the desaturase reaction. It is suggested that the site of this involvement could be the terminal component of the microsomal electron transport chain.
\end{abstract}

Pigs maintained on diets supplemented with $250 \mathrm{mg}$ copper $/ \mathrm{kg}$ diet show increased growth rates (see Braude, 1967 ). The increased dietary $\mathrm{Cu}$ is associated with softening of the adipose tissue (Taylor \& Thomke, 1964) due partly to the increase in the proportions of $16: 1$ and 18 :I fatty acids relative to the corresponding saturated acids (Elliot \& Bowland, I968; Moore, Christie, Braude \& Mitchell, 1969) and partly to changes in the stereospecific distribution of fatty acids within the triacylglycerol molecules (Christie \& Moore, 1969; Moore et al. 1969).

Recent reports have shown that the fatty acid desaturase activity in liver (Ho \& Elliot, 1973, I974; Thompson, Allen \& Meade, 1973) and adipose tissue (Ho \& Elliot, 1973, 1974) is increased in pigs given $\mathrm{Cu}$-supplemented diets and is probably responsible for the reported differences in fatty acid composition of the triacylglycerols. The addition of $\mathrm{Cu}$ ions in vitro is accompanied by increased activity and stability of desaturase in microsomes from pig liver (Thompson et al. 1973).

The purpose of the present work was to study the effect of dietary Cu deficiency in rats on $(a)$ the fatty acid composition of triacylglycerols and $(b)$ the desaturase activity of liver microsomes, in an attempt to find a possible $\mathrm{Cu}$ requirement for this reaction. A preliminary account of this work has been given (Wahle \& Davies, 1974). 


\section{MATERIALS AND METHODS}

\section{Animals and diets}

Male rats of the Hooded Lister strain were maintained from weaning to between 4 and 16 weeks of age on a semi-synthetic diet (Williams \& Mills, 1970) containing $(/ \mathrm{kg}): 200 \mathrm{~g}$ albumin, $600 \mathrm{~g}$ sucrose, $100 \mathrm{~g}$ arachis oil, and 0.6 (deficient), 3, 12 or 25 (adequate) $\mathrm{mg} \mathrm{Cu}$ as $\mathrm{CuSO}_{4} \cdot 5 \mathrm{H}_{2} \mathrm{O}$, and sufficient vitamins and minerals. Animals were housed in polypropylene cages and only in pair-feeding experiments were the rats caged individually.

\section{Tissue preparations and assays}

Animals were anaesthetized by intraperitoneal injection of Nembutal (Abbot Laboratories Ltd, Agro-Vet Division, Queenborough, Kent MEı I ${ }_{5} \mathrm{EL}$ ) (45 mg/kg body-weight); blood was taken by cardiac puncture and the livers and samples of perinephric and subcutaneous adipose tissue were removed.

Desaturase estimation. The preparation of the microsomes and the estimation of fatty acid desaturase activity were done as described previously (Wahle, 1974).

Fatty acid determination. Extraction of adipose tissue triacylglycerols and the preparation and determination of their main constituent fatty acids as methyl esters by gas-liquid chromatography were done using the method of Duncan \& Garton (1967).

Plasma $\mathrm{Cu}$ concentrations. The heparinized blood samples were centrifuged and I $\mathrm{ml}$ portions of plasma were mixed with $\mathrm{I} \mathrm{ml}$ trichloroacetic acid (TCA; $100 \mathrm{~g} / \mathrm{l}$ ) and centrifuged again to remove precipitated protein. The $\mathrm{Cu}$ concentrations were determined by atomic absorption spectrophotometry. Standard $\mathrm{Cu}$ solutions were prepared in TCA $(5 \circ \mathrm{g} / \mathrm{l})$.

Tissue Cu concentrations. Liver ( $0.5 \mathrm{~g}$ wet weight) was freeze-dried, ground to a powder and approximately $50 \mathrm{mg}$ was digested in conc. $\mathrm{HNO}_{3}$-conc. $\mathrm{HClO}_{4}$-conc. $\mathrm{H}_{2} \mathrm{SO}_{4}$ (5: $\mathrm{r}: 0 \cdot 5$, by vol.). The conc. $\mathrm{HNO}_{3}$-conc. $\mathrm{HClO}_{4}$ was removed by boiling and the residual $\mathrm{H}_{2} \mathrm{SO}_{4}$ diluted to $10 \mathrm{ml}$. The $\mathrm{Cu}$ content was determined by atomic absorption spectroscopy using $\mathrm{Cu}$ standards prepared in a solution of $50 \mathrm{ml}$ conc. $\mathrm{H}_{2} \mathrm{SO}_{4} / \mathrm{l}$.

Cytochrome c oxidase activity. The liver samples were homogenized $(\mathrm{I}: 100, \mathrm{w} / \mathrm{v})$ in 5 mM-EDTA-Tris buffer, $\mathrm{pH} 74$, using a glass homogenizer and Teflon pestle. The resulting homogenates were centrifuged at $1000 \mathrm{~g}$ and the supernatant fractions used for the estimation of cytochrome $c$ oxidase activity using the method of Mills \& Dalgarno (1970).

Caeruloplasmin activity. The method of Houchin (1958) as modified by Rice (1960) was used and the results were expressed in IU as defined by Rice (1962).

Protein concentration. This was determined using the method of Miller (1959).

Chemicals. Neocuproine (2,9-dimethyl-1,10-phenanthroline hemihydrate), ATP, $\mathrm{NADH}$, coenzyme A, L-glycerol-3-phosphate and N-acetylcysteine were obtained from Sigma (London) Chemical Co. Ltd, Kingston-upon-Thames, Surrey. $\left[\mathrm{I}^{14} \mathrm{C}\right]-$ 

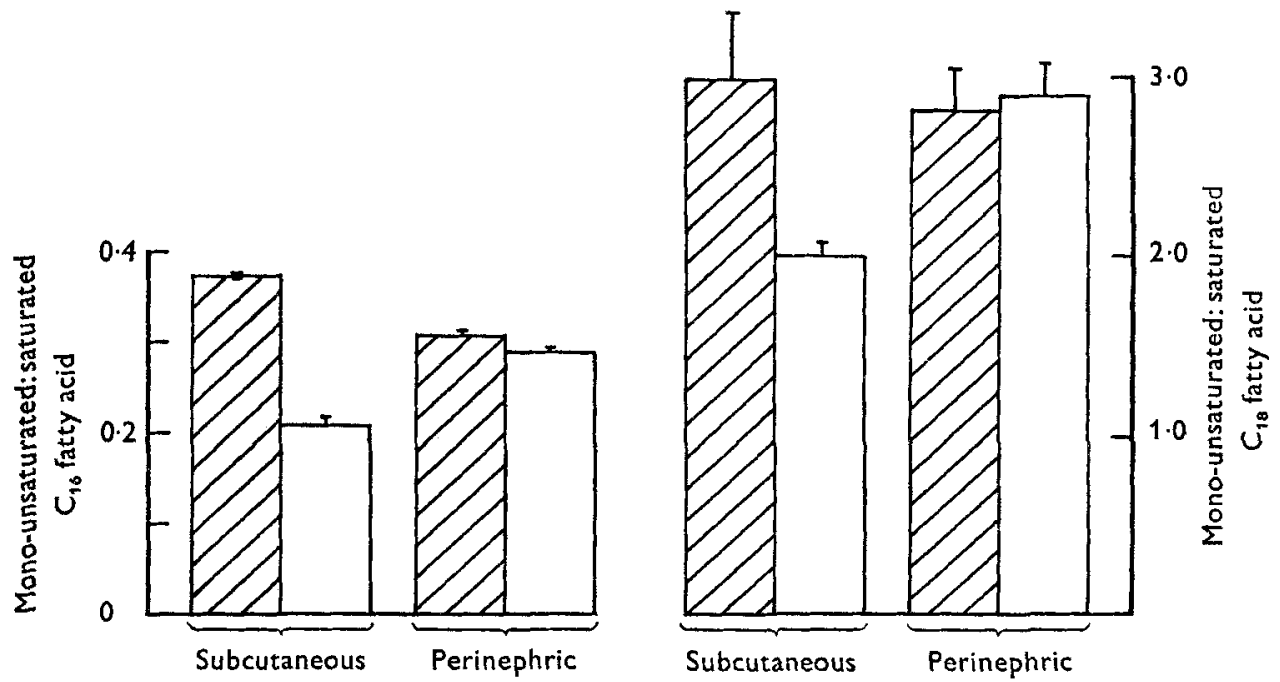

Fig. I. Ratios of concentrations of mono-unsaturated: saturated for $C_{16}$ and $C_{18}$ fatty acids in triacylglycerols of adipose tissue from rats maintained on $\mathrm{Cu}$-adequate $(\square)$ and $\mathrm{Cu}$-deficient ( $\square$ ) semi-synthetic diets; for details of diets, see p. I06. Mean values with their standard etrors, represented by vertical bars, for four animals.

Table I. Desaturation of $\left[\mathrm{I}^{-14} \mathrm{C}\right]$ stearic acid by liver microsomes from rats fed to appetite or pair-fed on copper-adequate or Cu-deficient semi-synthetic diets*

(Mean values with their standard errors; number of animals in parentheses)

\begin{tabular}{|c|c|c|c|c|c|c|c|}
\hline & \multirow[b]{2}{*}{ Treatment } & \multicolumn{2}{|c|}{$\mathrm{Cu}$-adequate } & \multicolumn{2}{|c|}{$\mathrm{Cu}$-deficient } & \multicolumn{2}{|c|}{ Decrease $(\%)$} \\
\hline & & Mean & SE & Mean & $\mathbf{S E}$ & Mean & $\mathrm{se}$ \\
\hline \multirow{2}{*}{$\begin{array}{l}\text { Desaturase activity } \dagger \\
\text { (nmol } 18: 0 \text { fatty acid } \\
\text { converted to } 18: 1 / 30 \mathrm{~min} \\
\text { per mg protein) }\end{array}$} & Fed to appetite & $70 \cdot 2$ & $13 \cdot 5$ & 20.7 & $6 \cdot 0$ & $64 \cdot 5$ & $14 \cdot 1$ \\
\hline & Pair-fed & $42 \cdot 6$ & 5.4 & $2 \pi \cdot 6$ & $2 \cdot I$ & $46 \cdot 4$ & $10 \cdot 7$ \\
\hline \multirow[t]{2}{*}{ Carcass weight (g) } & Fed to appetite & $354 \cdot 5$ & $6 \cdot 2$ & $291 \cdot 0$ & $8 \cdot 8$ & & \\
\hline & Pair-fed & $198 \cdot 2$ & II. 5 & $22 \mathrm{I} \cdot 5$ & $8 \cdot I$ & & \\
\hline
\end{tabular}

stearic acid was supplied by The Radiochemical Centre, Amersham, Bucks. All other chemicals were of AR grade, purchased from BDH Chemicals Ltd, Poole, Dorset.

\section{EXPERIMENTAL AND RESULTS}

The mean mono-unsaturated:saturated ratios for $\mathrm{C}_{16}$ and $\mathrm{C}_{18}$ fatty acids were significantly lower in the triacylglycerols of subcutaneous adipose tissue from rats maintained on the $\mathrm{Cu}$-deficient diet compared with those maintained on the $\mathrm{Cu}$ - 
Table 2. Desaturation of $\left[\mathrm{I}^{-14} \mathrm{C}\right]$ stearic acid by liver microsomes from rats maintained on semi-synthetic diets* differing in copper content, incubated with and without the Cuchelator Neocuproine ( $10 \mu \mathrm{mol} / \mathrm{ml}$ incubation medium)

(Mean values for two determinations)

$\begin{array}{lccc} & \begin{array}{c}0.6 \\ \text { (deficient) }\end{array} & 3.0 & 12.0 \\ \text { Desaturase activity } \dagger & 51.6 & 109.5 & \\ \text { Without Neocuproine } & \text { nd } & 112.8 & 106.5 \\ \text { With Neocuproine } & & 115.5\end{array}$

nd, Not determined.

* For details of diets, see p. ro6.

$+\mathrm{nmol}$ i 8:0 fatty acid converted to $18: 1 / 30 \mathrm{~min}$ per $\mathrm{mg}$ protein; for details of procedures, see Wahle (1974).

Table 3. Effect of repletion of copper-deficient rats by feeding with a Cu-adequate diet (25 mg Cu/kg) or by intraperitoneal injection of doses of $300 \mu \mathrm{g} \mathrm{Cu}$ as $\mathrm{CuSO}_{4}$ in $\mathrm{I}_{\mathrm{I}} \circ \mathrm{O} \mathrm{ml}$ saline $(9 \mathrm{~g} \mathrm{NaCl} / \mathrm{l}), 2$ and $7 d$ before killing, on fatty acid desaturase activity of liver microsomes and indices of Cu status

(Mean values with their standard errors for three animals/group)

\begin{tabular}{|c|c|c|c|c|c|c|c|c|c|c|}
\hline ( & \multicolumn{2}{|c|}{$\begin{array}{l}\text { Cu-adequate } \\
\text { (control) }\end{array}$} & \multicolumn{2}{|c|}{$\begin{array}{l}\text { Cu-adequate } \\
+ \text { injected } \mathrm{Cu}\end{array}$} & \multicolumn{2}{|c|}{$\mathrm{Cu}$-deficient } & \multicolumn{2}{|c|}{$\begin{array}{l}\text { Cu-deficient } \\
+ \text { injected } \mathrm{Cu}\end{array}$} & \multicolumn{2}{|c|}{$\begin{array}{l}\mathrm{Cu} \text {-deficient } \\
\text { fed } \mathrm{Cu}- \\
\text { adequate diet }\end{array}$} \\
\hline & Mean & $\mathrm{SE}$ & Mean & $\mathrm{SE}$ & Mean & $\mathrm{SE}$ & Mean & $\mathrm{SE}$ & Mean & $\mathrm{SE}$ \\
\hline $\begin{array}{l}\text { Desaturase activity } \\
\text { (nmol } 18: 0 \text { fatty acid } \\
\text { converted to } 18: 1 / 30 \mathrm{~min} \\
\text { per mg protein) }\end{array}$ & $48 \cdot 3$ & $7 \cdot 2$ & $44^{\cdot I}$ & 20.4 & 16.5 & $4 \cdot 8$ & $42 \cdot 3$ & 6.0 & $39 \cdot 3$ & 3.6 \\
\hline $\begin{array}{l}\text { Liver } \mathrm{Cu} \text { concentration } \\
(\mathrm{mg} / \mathrm{kg} \text { dry } \mathrm{wt})\end{array}$ & 147 & 0.7 & $32 \cdot 0$ & $8 \cdot \mathrm{I}$ & $5 \cdot 8$ & $1 \cdot 4$ & $24 \cdot 3$ & $4 \cdot 5$ & 15.9 & 0.5 \\
\hline $\begin{array}{l}\text { Liver cytochrome } c \\
\text { oxidase activity ( } \mu \text { mol } \\
\text { cytochrome } c \text { oxidized/ } \\
\text { min per mg protein) }\end{array}$ & 0.54 & 0.07 & 0.51 & 0.02 & 0.24 & 0.06 & $0.4 I$ & 0.03 & 0.45 & 0.01 \\
\hline $\begin{array}{l}\text { Plasma } \mathrm{Cu} \text { concentration } \\
(\mu \mathrm{g} / \mathrm{ml})\end{array}$ & $\begin{array}{r}I \cdot 4 \\
(I \cdot I 4,\end{array}$ & $\begin{array}{l}t \\
67)\end{array}$ & 1.58 & 0.10 & 0.4 & 0.14 & I. 6 & 0.4 & $I \cdot 3$ & 0.1 \\
\hline $\begin{array}{l}\text { Caeruloplasmin activity } \\
\left(\mathrm{IU}^{*} / 1\right)\end{array}$ & $\begin{array}{r}43 \cdot \\
(41 \cdot 9\end{array}$ & $4 \cdot 0)$ & $63 \cdot 5$ & $3 \cdot 5$ & $\mathrm{I} \cdot 5$ & I.O & $68 \cdot 5$ & $9 \cdot 8$ & $5 I \cdot 3$ & 4.4 \\
\hline
\end{tabular}

For details of experimental procedures, see pp, 109 and 1 ro.

* For definition of unit, see Rice ( 1962 ).

$\uparrow$ Mean values for two animals.

adequate diet (Fig. I). In perinephric adipose tissue there were no differences between the $\mathrm{Cu}$-deficient and $\mathrm{Cu}$-adequate rats with respect to these ratios for $\mathrm{C}_{16}$ and $\mathrm{C}_{18}$ fatty acids.

The desaturation of $\left[\mathrm{I}^{14} \mathrm{C}\right]$ stearic acid to oleic acid was substantially decreased in microsomes from the liver of $\mathrm{Cu}$-deficient rats compared with control ( $\mathrm{Cu}$-adequate) animals (Table I). The lower food intakes and consequently decreased carcass weights 


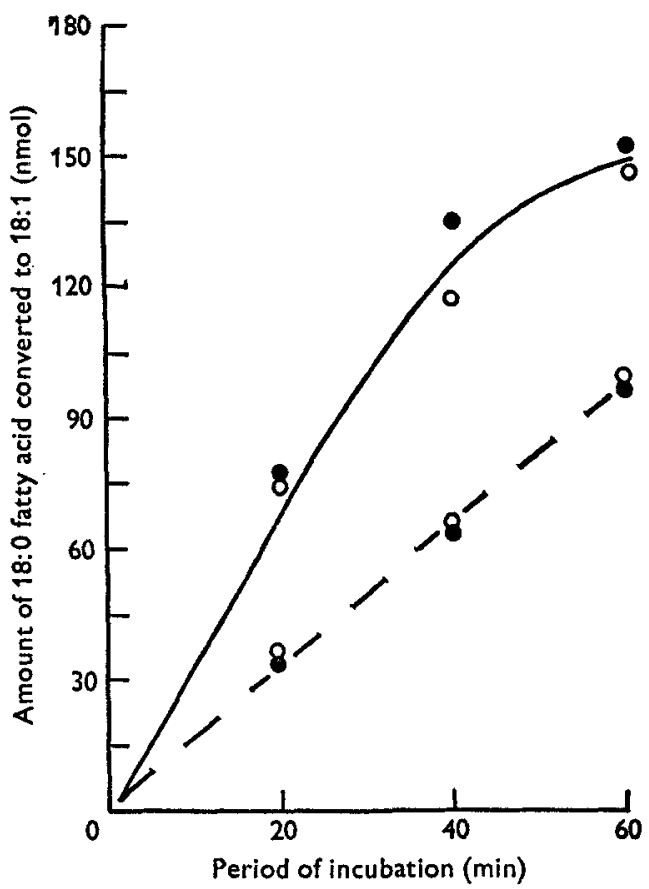

Fig. 2. The in vitro activity and stability of fatty acid desaturase of liver microsomes from rats maintained on $\mathrm{Cu}$-adequate $(-)$ or $\mathrm{Cu}$-deficient (--) semi-synthetic diets (0.6 and $25 \mathrm{mg} \mathrm{Cu} / \mathrm{kg}$ respectively), incubated with $(O)$ or without $(\odot)$ added cupric ions (30 $\mathrm{nmol}$ $\mathrm{CuSO}_{4} / \mathrm{mg}$ microsomal protein); for details of procedures, see Wahle (1974). Each point represents the mean value for two determinations.

of the $\mathrm{Cu}$-deficient animals compared with the control animals may have effected the decreased desaturase activity in these animals. Control rats were therefore pair-fed with $\mathrm{Cu}$-deficient animals with the result that carcass weights were not significantly different, but the decreased desaturase activity was still evident.

Microsomes from livers of $8 \cdot 5$-week-old rats, maintained from weaning on diets containing $0.6 \mathrm{mg} \mathrm{Cu} / \mathrm{kg}$ (Cu-deficient), had desaturase activities approximately $50 \%$ lower than those from rats given diets containing 3.0 or $12.0 \mathrm{mg} \mathrm{Cu} / \mathrm{kg}$ (Table 2). The carcass weights of these animals were similar. These results suggest that the decreased desaturase activity was due to the $\mathrm{Cu}$ deficiency rather than decreased food intake. The addition of Neocuproine (Io $\mu \mathrm{mol} / \mathrm{ml}$ incubation medium), a specific $\mathrm{Cu}$-chelating agent, to the liver microsomes in vitro did not affect their desaturase activity.

$\mathrm{Cu}$-deficient rats were repleted with $\mathrm{Cu}$ either by allowing them access to the $\mathrm{Cu}$ adequate diet $(25 \mathrm{mg} \mathrm{Cu} / \mathrm{kg}$ ) for $\mathrm{I} 2 \mathrm{~d}$ before killing or by injecting intraperitoneally doses of $300 \mu \mathrm{g} \mathrm{Cu}$ as $\mathrm{CuSO}_{4}$ in $\mathrm{r} \cdot 0 \mathrm{ml}$ sterile saline solution $(9 \mathrm{~g} \mathrm{NaCl} / \mathrm{l}) 7$ and $2 \mathrm{~d}$ before killing; a group of control (Cu-adequate) rats was similarly injected with $\mathrm{Cu}$. The desaturase activity of liver microsomes, liver $\mathrm{Cu}$ concentrations and cytochrome $c$ oxidase activities are shown in Table 3 . A reduced desaturase activity was again found for microsomes from the $\mathrm{Cu}$-deficient rats, but this was restored to 'control' values 
by both methods of $\mathrm{Cu}$-repletion. The injection of $\mathrm{Cu}$ into control rats did not increase the desaturase activity of liver microsomes, although the liver $\mathrm{Cu}$ concentrations were approximately twice those found for untreated control animals. The $\mathrm{Cu}$ injections also increased liver $\mathrm{Cu}$ concentrations for the $\mathrm{Cu}$-deficient rats to values greater than those found for control rats. Liver cytochrome $c$ oxidase (a known $\mathrm{Cu}$-containing enzyme) showed the same decrease and restoration of activity with $\mathrm{Cu}$ depletion and repletion as desaturase activity; plasma $\mathrm{Cu}$ concentrations and caeruloplasmin activities followed the same pattern.

The addition of $\mathrm{CuSO}_{4}(30 \mathrm{nmol} / \mathrm{mg}$ microsomal protein) to the incubation medium had no effect on the in vitro activity or stability of the desaturase activity of liver microsomes from Cu-deficient or control rats (Fig. 2). $\mathrm{CuSO}_{4}$ concentrations of $200 \mathrm{nmol} / \mathrm{mg}$ microsomal protein, or above, inhibited desaturase activity, the inhibition being greater in microsomes from the livers of control rats. The addition of $\mathrm{FeCl}_{3}$ at various concentrations to the incubation medium had no effect on the desaturase activity of microsomes in vitro.

\section{DISCUSSION}

Dietary $\mathrm{Cu}$ deficiency resulted in decreased mono-unsaturated:saturated ratios for $\mathrm{C}_{16}$ and $\mathrm{C}_{18}$ fatty acids of the triacylglycerols from subcutaneous tissue when compared with those for control rats. The apparent decrease in the capacity of these animals to effect the mono-desaturation of long-chain saturated fatty acids was reflected in the decreased extent of desaturation of stearic acid to oleic acid by liver microsomes. Palmitic acid and stearic acid are desaturated in animals by the same enzyme system except that the enzyme has a lower affinity for the former (Brett, Howling, Morris \& James, I97I). The higher mono-unsaturated:saturated ratios for $\mathrm{C}_{16}$ and $\mathrm{C}_{18}$ fatty acids of the triacylglycerols of subcutaneous adipose tissue from pigs given $\mathrm{Cu}$-supplemented diets (Ho \& Elliot, 1973; Thompson et al. 1973) and the increased desaturase activity for microsomes from liver (Thompson et al. I973) and from adipose tissue (Ho \& Elliot, I973) when compared with those for control pigs would appear to complement the findings for Cu-deficient rats. However, the extent to which increased food consumption of the $\mathrm{Cu}$-supplemented pigs influenced their fatty acid desaturase activity and consequently the fatty acid composition of the triacylglycerols of adipose tissue was not investigated. The pair-feeding of control (Cu-adequate) rats to $\mathrm{Cu}$ deficient animals precluded influences on desaturase activity ascribable to differences in food intake (see Gellhorn \& Benjamin, 1964) as found for non-pair-fed animals. Decreased desaturase activity for the $\mathrm{Cu}$-deficient rats compared with their pair-fed controls can therefore be regarded as being due to $\mathrm{Cu}$ deficiency per se and not to decreased food intake. Differences in desaturase activity between control rats pair-fed to $\mathrm{Cu}$-deficient animals and control rats fed to appetite on the $\mathrm{Cu}$-adequate diet probably reflected the influence of differences in dietary intake on the desaturase enzyme system. A concentration of $3 \mathrm{mg} \mathrm{Cu} / \mathrm{kg}$ diet seemed adequate for maintenance of the desaturase activity in rat liver microsomes, since higher concentrations had no further effect.

The reason for the lack of effect of $\mathrm{Cu}$ deficiency in the rat on the fatty acid com- 


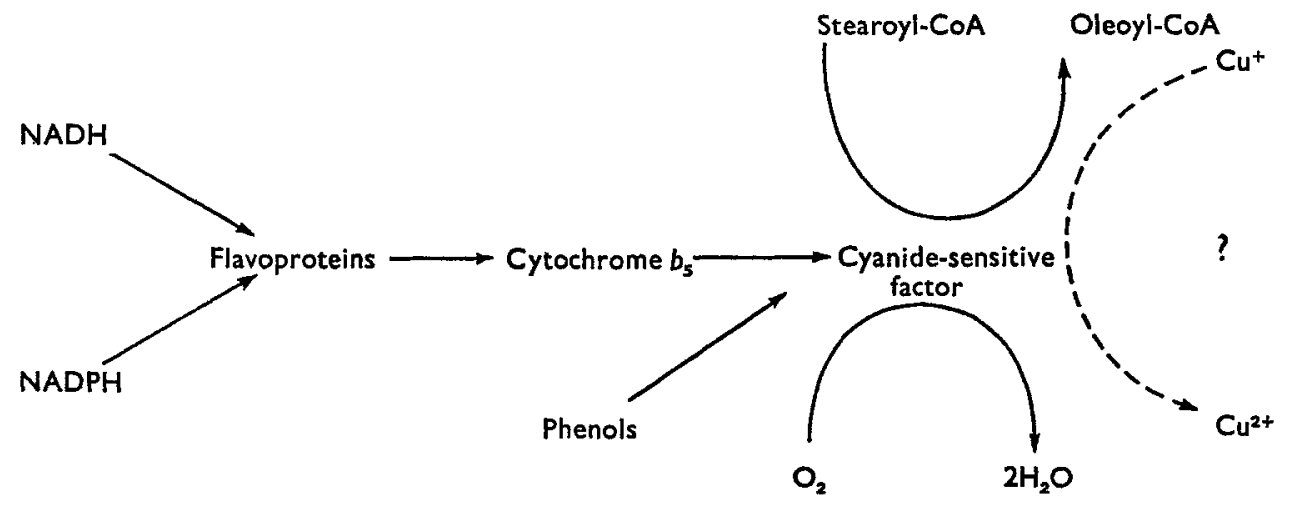

Fig. 3. Microsomal electron transport system associated with fatty acid desaturation (after Oshino \& Sato, I972) showing the possible site for involvement of copper.

position of perinephric adipose tissue similar to that found for subcutaneous adipose tissue is not clear. It is noteworthy that the feeding of $\mathrm{Cu}$-supplemented diets to pigs similarly had little effect on the fatty acid composition of the triacylglycerols of the perinephric adipose tissue (Thompson et al. 1973). Microsomes from adipose tissue of pigs had greater desaturase activity than did those from liver; however, increased dietary $\mathrm{Cu}$ enhanced desaturase activity in both tissues (Ho \& Elliot, r973). In rats, the desaturase activity for liver microsomes was greater than that for adipose tissue (Wahle, 1974); the former were therefore used for subsequent desaturase determinations. However, it was assumed, by analogy with the pig, that the desaturase activity of subcutaneous adipose tissue from the rat was also influenced by dietary $\mathrm{Cu}$ deficiency in a similar manner to liver microsomes.

The restoration, either by dietary $\mathrm{Cu}$ or intraperitoneal injection of $\mathrm{Cu}$, of the decreased activities for liver desaturase and cytochrome $c$ oxidase (a known $\mathrm{Cu}$ enzyme), as well as the restoration of other indices of $\mathrm{Cu}$ status in the $\mathrm{Cu}$-deficient rats, strongly indicated that $\mathrm{Cu}$ may be involved in the desaturase reaction. When $\mathrm{Cu}$ was injected intraperitoneally into $\mathrm{Cu}$-deficient rats, liver $\mathrm{Cu}$ levels in excess of control values were found, but liver desaturase activity was not greater than that for control animals as it was for pigs given $\mathrm{Cu}$-supplemented diets. Similarly, the addition of $\mathrm{CuSO}_{4}$ in vitro to liver microsome preparations from rats did not enhance desaturase activity as it did for those from pigs (Thompson et al. 1973).

Although these findings are indicative of an involvement of $\mathrm{Cu}$ in the microsomal desaturase reaction neither its location within the sequence of reactions constituting the desaturase reaction nor its function therein is known.

The desaturase reaction requires a functional microsomal electron transport chain (ETC), the terminal component of which is inhibited by cyanide and is regarded as the desaturase enzyme (Oshino, Imai \& Sato, I966; Oshino \& Sato, I972) (Fig. 3). Electrons from reduced pyridine nucleotides pass via flavoproteins and cytochrome $b_{5}$ to the cyanide-sensitive factor (CSF) which, in its reduced state, activates molecular oxygen and interacts with long-chain acyl-CoA derivatives to produce the corresponding mono-unsaturated derivatives (Oshino, Imai \& Sato, 1966, 1971). The CSF 
is capable of reacting direct with phenols such as $p$-cresol (Oshino \& Sato, 1971) which are the usual substrates for the enzyme phenolase in plants, or tyrosinase in mammalian tissues. This is an established $\mathrm{Cu}$ enzyme incorporating a cuprous-cupric valency shift in its reaction mechanism. Such Cu enzymes can usually only use molecular oxygen as the electron acceptor, making them ideally suited as terminal components of electron transport chains (see Mahler \& Cordes, 1966). These properties, along with the indications that the CSF may not be a haem-protein (Shimakata, Mihara \& Sato, 1972), led us to postulate that $\mathrm{Cu}$ could be involved in the terminal stage of the microsomal ETC in a manner analogous to that of cytochrome oxidase in the mitochondrial ETC (see Fig. 3). Preliminary determinations of the $\mathrm{Cu}$ concentration in the components of the microsomal ETC, isolated using the method of Shimakata et al. (1972), indicated a higher $\mathrm{Cu}$ content in the CSF than in the other components (Davies \& Wahle, unpublished results). However, the preparations were not homogeneous and the preliminary nature of these findings must be emphasized. Further work is in progress to purify and analyse the CSF in detail.

We wish to thank Miss A. R. Burnett and Mr A. Flett for their able technical assistance and $\mathrm{Mr} \mathrm{R}$. B. Williams for supplying some of the rat tissues.

\section{REFEREN CES}

Braude, R. (1967). Wld Rev. Anim. Prod. 3,69.

Brett, D., Howling, D., Morris, L. J. \& James, A. T. (r971). Archs Biochem. Biophys. 143, 535.

Christie, W. W. \& Moore, J. H. (I969). Lipids 4, 345.

Duncan, W. R. H. \& Garton, G. A. (1967). J. Sci. Fd Agric. 18, 99.

Elliot, J. I. \& Bowland, J. P. (1968). Y. Anim. Sci. 27, 956.

Gellhorn, A. \& Benjamin, W. (x964). Biochim. biophys. Acta 84, I67.

Ho, S. K. \& Elliot, J. I. (1973). Can. Y. Anim. Sci. 53, 537.

Ho, S. K. \& Elliot, J. I. (1974). Can. F. Anim. Sci. 54, 23.

Houchin, O. B. (1958). Clin. Chem. 4, 519.

Mahler, H. R. \& Cordes, E. H. (1966). Biological Chemistry, p. 569. New York and London: Harper and Row.

Miller, G. L. (1959). Analyt. Chem. 31, 964.

Mills, C. F. \& Dalgarno, A. C. (1970). In Trace Element Metabolism in Animals, p. 456 [C. F. Mills, editor]. Edinburgh and London: E. \& S. Livingstone.

Moore, J. H., Christie, W. W., Braude, R. \& Mitchell, K. G. (1969). Br. F. Nutr. 23, 28 r.

Oshino, N., Imai, Y. \& Sato, R. (1966). Biochim. biophys. Acta 128, 13.

Oshino, N., Imai, Y. \& Sato, R. (197r). F. Biochem., Tokyo 69, 155.

Oshino, N. \& Sato, R. (I971). F. Biochem., Tokyo 69, I69.

Oshino, N. \& Sato, R. (1972). Archs Biochem. Biophys. 149, 369.

Rice, E. W. (1960). Clinica chim. Acta 5, 632.

Rice, E. W. (1962). Analyt. Biochem. 3, 452 .

Shimakata, T., Mihara, K. \& Sato, R. (1972). F. Biochem., Tokyo 72, I $6_{3}$.

Taylor, M. \& Thomke, S. (1964). Nature, Lond. 201, 1246.

Thompson, E. H., Allen, C. E. \& Meade, R. J. (r973). F. Anim. Sci. 36, 868.

Wahle, K. W. J. (1974). Comp. Biochem. Physiol. $48 \mathrm{~B}, 87$.

Wahle, K. W. J. \& Davies, N. 'T. (1974). Biochem. Soc. Trans. 2, 1283.

Williams, R. B. \& Mills, C. F. (I970). Br. F. Nutr. 24, 989. 